\title{
A systematic review of causes of sudden and severe headache (Thunderclap Headache): should lists be evidence based?
}

\author{
Emma Devenney, Hazel Neale and Raeburn B Forbes*
}

\begin{abstract}
Background: There are many potential causes of sudden and severe headache (thunderclap headache), the most important of which is aneurysmal subarachnoid haemorrhage. Published academic reviews report a wide range of causes. We sought to create a definitive list of causes, other than aneurysmal subarachnoid haemorrhage, using a systematic review.

Methods: Systematic Review of EMBASE and MEDLINE databases using pre-defined search criteria up to September 2009. We extracted data from any original research paper or case report describing a case of someone presenting with a sudden and severe headache, and summarized the published causes.

Results: Our search identified over 21,000 titles, of which 1224 articles were scrutinized in full. 213 articles described 2345 people with sudden and severe headache, and we identified 6 English language academic review articles. A total of 119 causes were identified, of which 46 (38\%) were not mentioned in published academic review articles. Using capture-recapture analysis, we estimate that our search was $98 \%$ complete. There is only one population-based estimate of the incidence of sudden and severe headache at 43 cases per 100,000. In cohort studies, the most common causes identified were primary headaches or headaches of uncertain cause. Vasoconstriction syndromes are commonly mentioned in case reports or case series. The most common cause not mentioned in academic reviews was pneumocephalus. 70 non-English language articles were identified but these did not contain additional causes.

Conclusions: There are over 100 different published causes of sudden and severe headache, other than aneurysmal subarachnoid haemorrhage. We have now made a definitive list of causes for future reference which we intend to maintain. There is a need for an up to date population based description of cause of sudden and severe headache as the modern epidemiology of thunderclap headache may require updating in the light of research on cerebral vasoconstriction syndromes.
\end{abstract}

Keywords: Thunderclap headache; Sudden headache; Acute headache; Systematic review; Publication bias

\section{Background}

Sudden and Severe Headache is a common reason for seeking urgent medical advice [1], primarily to exclude aneurysmal subarachnoid haemorrhage [2].

In the process of developing a guideline for managing acute headache we observed variation in the range of diagnoses published [3-9], so we conducted a systematic review of literature to compile a comprehensive list of potential causes other than aneurysmal subarachnoid haemorrhage.

\footnotetext{
* Correspondence: raeburnforbes@southern.trust.hscni.net Department of Neurology and Medical Library, Craigavon Area Hospital, Southern HSC Trust, County Armagh, Northern Ireland BT63 5QQ, UK
}

We estimate completeness of ascertainment of causes using capture-recapture methods, and discuss the implications of using systematic review methods for lists of causation, paying attention to the issue of publication bias.

\section{Methods}

We searched MEDLINE and EMBASE databases in September 2009 using pre-specified search criteria (Table 1), designed and implemented by a professional librarian $(\mathrm{HN})$, as the Medical Subject Heading (MeSH term) for Thunderclap Headache excludes articles indexed prior 
Table 1 Search criteria to identify articles on sudden and severe headache (performed September 2009)

\begin{tabular}{|c|c|c|c|c|c|}
\hline \multirow{2}{*}{$\begin{array}{l}\text { Ovid MEDLINE(R) } \\
\text { Search terms }\end{array}$} & & \multicolumn{4}{|l|}{ EMBASE } \\
\hline & & Search terms & 1996-2009 & 1988-95 & $1980-87$ \\
\hline 1. headache/di, ep, et, co, mo, cf, ra & & 1. exp primary headache/ & 165 & 0 & 0 \\
\hline 2. headache disorders, primary/ & & 2. exp cough headache/ & 15 & 0 & 0 \\
\hline 3. vascular headaches/ & & 3. exp exertional headache/ & 17 & 0 & 1 \\
\hline 4. intracranial hypertension/ & & 4. exp hypnic headache/ & 81 & 0 & 0 \\
\hline 5. intracranial hypotension/ & & 5. exp postural headache/ & 24 & 1 & 0 \\
\hline 6. pseudotumor cerebri/ & & 6. exp secondary headache/ & 43 & 0 & c \\
\hline 7. intracranial vasospasm/ & & 7. exp thunderclap headache/ & 84 & 0 & 9 \\
\hline \multicolumn{2}{|l|}{$\begin{array}{l}\text { 8. (acute disease/ or catastrophic illness.mp. or critical } \\
\text { illlness/ or emergencies/) and (headache/ or headache } \\
\text { disorder/) [mp=title, original title, abstract, name of } \\
\text { substance word, subject heading word] }\end{array}$} & 8. exp vascular headache/ & 88 & 0 & 1 \\
\hline \multicolumn{2}{|l|}{ 9. 7 and (headache/ or headache disorder/) } & $\begin{array}{l}\text { 9. (coitus/ or orgasm/) and exp "headache } \\
\text { and facial pain"/ }\end{array}$ & 118 & 14 & 7 \\
\hline \multicolumn{2}{|l|}{ 10. thunderclap headache?.mp. } & $\begin{array}{l}\text { 10. exp acute disease/ and exp "headache } \\
\text { and facial pain"/ }\end{array}$ & 624 & 17 & 20 \\
\hline \multicolumn{2}{|l|}{ 11. coit*.mp. and (headache/ or headache disorder/) } & 11. exp intracranial hypotension/ & 589 & 8 & 11 \\
\hline \multicolumn{2}{|l|}{ 12. call fleming.mp. } & $\begin{array}{l}\text { 12. exp brain pseudotumor/ and exp } \\
\text { "headache and facial pain"/ }\end{array}$ & 387 & 60 & 2 \\
\hline \multicolumn{2}{|l|}{ 13. worst headache?.mp. } & $\begin{array}{l}\text { 13. exp brain vasospasm/ and exp "headache } \\
\text { and facial pain"/ }\end{array}$ & 181 & 18 & 11 \\
\hline \multicolumn{2}{|l|}{ 14. sentinel headache?.mp. } & 14. thunderclap headache?.mp. & 165 & 11 & 0 \\
\hline \multicolumn{2}{|l|}{ 15. explosive headache?.mp. } & 15. coit*.mp. and exp "headache and facial pain"/ & 61 & 16 & 1 \\
\hline \multicolumn{2}{|l|}{ 16. reversible cerebral vaso*.mp. } & 16. call fleming.mp. & 16 & 0 & 3 \\
\hline \multicolumn{2}{|l|}{ 17. postpartum angio*.mp. } & 17. worst headache?.mp. & 21 & 5 & 0 \\
\hline \multicolumn{2}{|l|}{ 18. postpartum vasc*.mp. } & 18. sentinel headache?.mp. & 14 & 3 & 0 \\
\hline \multirow{3}{*}{\multicolumn{2}{|c|}{$\begin{array}{l}\text { 19. } 1 \text { or } 2 \text { or } 3 \text { or } 4 \text { or } 5 \text { or } 6 \text { or } 7 \text { or } 8 \text { or } 9 \text { or } 10 \text { or } \\
11 \text { or } 13 \text { or } 14 \text { or } 15 \text { or } 16 \text { or } 17 \text { or } 18\end{array}$}} & 19. explosive headache?.mp. & 6 & 1 & 0 \\
\hline & & 20. reversible cerebral vaso*.mp. & 45 & 1 & 66 \\
\hline & & 21. postpartum angiopathy.mp. & 14 & 0 & 57 \\
\hline Gross total references & 20338 & Gross total references & 2758 & 155 & 57 \\
\hline Duplicates & 1547 & Duplicate references & 18 & 14 & 0 \\
\hline Net total references from MEDLINE & 18791 & Net total references & 2395 & 141 & 57 \\
\hline \multicolumn{5}{|l|}{ All references Identified } & 21384 \\
\hline
\end{tabular}

to November 1999 [10]. We screened titles of publications for potential cases, case series, cohort studies or academic reviews of people with a sudden AND severe headache. Cases were included if the presenting headache was both sudden in onset AND severe in intensity. Cases were excluded if a headache onset was not sudden or if onset was not reported (even the headache was severe or a significant aetiology was subsequently found). Similarly, if a sudden headache was described but there was no description of the severity of the pain, we excluded the case. We excluded publications concerning aneurysmal subarachnoid haemorrhage, as the major purpose of our systematic review was to identify other causes. Publications on Exploding Head Syndrome [11], Neuralgic disorders, such as Idiopathic Stabbing Headaches [12], or Trigeminal Neuralgia [13] were also excluded, as these are characteristic syndromes in their own right. However, these diagnoses could be included if they were reported as the final diagnosis in someone presenting with a sudden AND severe headache.

We included Academic Review articles, as we wanted to compare causes published in academic reviews with those obtained from the data sourced from our systematic review. Academic Review articles had to describe thunderclap headache or the differential diagnosis of thunderclap headache, and not just headache seen in the Emergency Department. We drew up lists of causes which were (a) identified in original articles only, (b) identified in 
academic review articles only and (c) identified in both original articles and academic reviews.

We were unable to use the International Headache Classification [14], as the majority of authors had not used criteria, and there was usually insufficient information to allow a retrospective classification. We therefore classified cases according to causation.

\section{Non-English publications}

We were not funded for translation services. Once we had completed the review of English publications, we used an online translation tool [15], and entered text from non-English articles to try and identify additional causes from non-English publications. As we were not able to have these papers translated professionally, we summarised these articles separately.

\section{Statistics and analysis}

We used descriptive, summary statistics and stratified our diagnostic categories according to whether the source cases were from case reports, case series or cohort studies.

We were specifically interested in whether there was variation between different study types, as publication bias would suggest that conditions that are rare in unselected populations would be over-represented in the medical literature. We were also interested in exploring any differences between lists of causes identified by Academic Review articles and the list we ultimately generated from our systematic review.

To assess the completeness of our diagnostic list we used a capture-recapture method to estimate the number of unobserved diagnoses [16].

We were advised by our local research ethics committee that formal approval was not required as this research did not involve human subjects, and was a systematic review of published literature.

\section{Results}

Our search strategy, executed in September 2009, identified 21,384 potential articles (Table 1). On review of titles we created a shortlist of 1224 publications. The abstracts of these 1224 full text articles were reviewed. 151 publications were duplicates (i.e. listed on both EMBASE and MEDLINE), leaving 1073 papers. Of these 1073, 70 required translation (which we did not have funding to do), and 27 were not traceable, even following inter-library loan requests.

Of the remaining 976 articles, 213 met inclusion criteria of describing a total of 2345 people with sudden and severe headache:

- 194 Case Report articles describing 321 people

- 13 Case Series articles describing 375 people

- 6 Cohort articles describing 1649 people.
Only one study had prospective, unselected populationbased information on the incidence of Sudden Headache estimating an annual incidence of 43 cases per 100,000 adults [17].

A further 6 articles were identified which were English Language Academic Review articles on Thunderclap Headache that described causes of sudden AND severe i.e. 'Thunderclap' headache $[3,4,6,7,18,19]$.

This systematic review is therefore based upon a total of 219 English publications (213 original articles and 6 academic reviews). The 764 articles excluded articles were reviews related to acute headache, the investigation of headache, editorial comment or publications of new onset headache where onset AND severity were not reported.

Of the 70 non-English articles, we excluded 29 after using an online translation tool. Of the remaining 41 non-English Language articles, 22 were case reports which included 29 cases, none of which reported causes of sudden and severe headache that were unreported in our English Language papers. There were 8 case series and 4 cohort studies looking at unselected series of people with acute headache. A further 6 non-English academic review articles were identified that examined thunderclap headache [20-25].

\section{Completeness of ascertainment of systematic review}

There were a total of 69 distinct clinical syndromes associated with Sudden AND Severe Headache that were mentioned in academic review articles AND were identified in our own literature search. We identified 46 distinct clinical syndromes associated with Sudden and Severe Headache that were unique to our systematically reviewed literature, and there were 4 diagnoses mentioned in the academic review articles as causes of Thunderclap Headache, but we did not find any citation in our own search strategy ('Crash Migraine', Hypnic Headache, Anterior Cerebral Artery Aneurysm (although we identified a case of middle cerebral artery aneurysm), and Cluster Headache).

If we assume that we missed these 4 causes, then our search strategy has probably identified about $98 \%$ of known causes of sudden and severe headache (Table 2).

\section{Relative frequency of causes, according to type of study}

The frequency of causes depended on the type of study performed (Table 3).

By definition, case reports and case series would not contain any people with sudden and severe headache in whom a cause was uncertain or unknown. There were no published case reports of common primary headaches, such as migraine, tension-type headache or cluster headache manifesting as sudden and severe headache (Table 3). On the other hand, Reversible Cerebral Vasoconstriction Syndromes were not explicitly mentioned in any of the 
Table 2 Estimated efficiency of systematic search for causes of sudden and severe headache

\begin{tabular}{lccc}
\hline & \multicolumn{2}{c}{ In academic review } \\
\cline { 2 - 4 } & & Yes & No \\
\hline In systematic review & Yes & $69^{* *}$ & 46 \\
& No & 4 & *Estimated 3 articles unobserved
\end{tabular}

*Where the number of unobserved cases is equal to $(46 \times 4) / 69$ (see reference $[16,26]$.

**If we count all vasoconstriction syndromes as one single cause, then the value of this cell in 45 , but the number of unobserved cases would still be close to 3 .

published cohort studies, but were common subjects of case series and case reports.

In cohort studies (Table 3), where neurologists were responsible for assigning diagnoses, the 'not-specified' populations (28\%) make the largest group of people. Overall, from cohort studies, $75 \%$ of cases of sudden and severe headache are assigned to either a primary headache disorder $(27 \%)$, a non-specific headache $(28 \%)$, Idiopathic Thunderclap Headache $(17 \%)$ or an uncertain headache disorder (3\%).

In cohort studies, a Cerebrovascular Disorder (17\%) is most the most likely identifiable cause. Cerebral Vasoconstriction Syndromes were not explicitly reported in any of the cohort studies, but systemic or CNS infections, including sinusitis, meningitis and viral illness are reasonably frequently associated with sudden and severe headache (7\%).

Cervicocephalic Arterial Dissection $(0.1 \%$ of cohort cases) and Cerebral Venous Sinus Thrombosis ( $0.2 \%$ of cohort cases) are often cited as causes of sudden and severe headache, and featured prominently from our case series and case reports, yet occur infrequently in cohort studies. Pituitary Apoplexy was not reported in any of the cohort studies.

Other rare causes from cohort studies that were not published in case reports included Acute Cranial Herpes Zoster [27], Herpes Encephalitis [28], HaNDL Syndrome [27], Cerebral Oedema [17,29] and Alcohol-Induced Headache [27].
Case series are usually single institution experiences of diagnosis and management of a single cause of sudden and severe headache. Cerebrovascular causes predominate, such as Reversible Cerebral Vasoconstriction Syndrome [30] (Table 3). In the Case Reports, cerebrovascular causes accounted for $47 \%$ of published cases (Table 3 ).

'Musculoskeletal headaches' were listed in one cohort study [31], but Bath-related Headache [32], Pituitary Apoplexy [33] and Occipital Neuralgia [34] were not mentioned in cohort studies. A series on unruptured intracranial aneurysm proposed that expansion or thrombosis could lead to symptoms without rupture or subarachnoid haemorrhage [35].

\section{Idiopathic thunderclap headache}

Of the 459 people we identified with Idiopathic Thunderclap Headache there were a range of provoking activities, including sexual activity, bathing, and exertion (Table 4). In these 459 cases vasoconstriction was not sought or if sought, was not identified.

\section{Infection associated thunderclap headache}

Cohort Studies identified infections in $7 \%$ of cases, and these were either unidentified infections or related to rhinosinusitis (Table 5). There has been at least one large series of aseptic meningitis where several cases presented with sudden and severe headache (Table 5). There are isolated case reports of sudden and severe headache which seem to be related to relatively rare infections such as Q-Fever and Erve Virus [68].

\section{Cerebrovascular disease}

We separated these cases into groups where there was no evidence of segmental arterial constriction nonvasoconstrictive aetiology (398 cases - Table 6) and vasoconstriction syndromes, (234 cases - Table 7).

A wide range of non-vasoconstrictive pathologies exist that could provoke sudden and severe headache, including all types of intracranial haemorrhage (subdural, subarachnoid, intracerebral and one single case of epidural

Table 3 Sudden AND severe headache causation by group and type of publication

\begin{tabular}{|c|c|c|c|c|c|c|c|c|}
\hline Cause & Cohort (N) & $\%$ & Case (N) & $\%$ & Case series & $\%$ & All (N) & $\%$ \\
\hline Idiopathic thunderclap headache & 265 & 16 & 87 & 27 & 107 & 29 & 459 & 20 \\
\hline Other, not specified & 457 & 28 & 18 & 6 & 0 & 0 & 475 & 20 \\
\hline Primary headache & 447 & 27 & 0 & 0 & 0 & 0 & 447 & 19 \\
\hline Cerebrovascular & 281 & 17 & 153 & 47 & 198 & 53 & 632 & 27 \\
\hline Infection & 119 & 7 & 17 & 5 & 24 & 6 & 160 & 7 \\
\hline Unknown & 49 & 3 & 0 & 0 & 0 & 0 & 49 & 2 \\
\hline Non-neurovascular & 27 & 2 & 46 & 14 & 46 & 12 & 119 & 5 \\
\hline Sudden death with headache & 4 & 0.2 & 0 & 0 & 0 & 0 & 4 & 0 \\
\hline Total & 1,649 & 100 & 321 & 99 & 375 & 100 & 2345 & 100 \\
\hline
\end{tabular}


Table $4 \mathbf{4 5 9}$ cases of idiopathic thunderclap headache, by study type and provocation

\begin{tabular}{llcc}
\hline Study type & Final diagnosis & N & Provocation \\
\hline Case & Bath-Related Thunderclap Headache [36-40] & 16 & Bathing \\
Series & Bath-Related Thunderclap Headache [32] & 21 & Bathing \\
Case & Weight lifters headache [41,42] & 3 & 7 \\
Case & Primary Exertional [43-45] & 17 & Exertion \\
Cohort & Primary Exertional Headache [27] & 2 & Exertion \\
Case & Swimming headache followed by exertional and coital headache [46] & 13 & Exertion \\
Case & Primary Thunderclap Headache [47-49]* & 200 & Idiopathic \\
Cohort & Primary Thunderclap Headache [27-29,50] & 42 & Sexual activity \\
Case & Headache Associated with Sexual Activity [51-63] & 48 & Sexual activity \\
Cohort & Headache Associated with Sexual Activity ([17,27,31] & 86 & Sexual activity \\
Series & Headache Associated with Sexual Activity [53,64,65] & 4 & Sexual activity \\
Case & Combined Benign Exertional and Benign Sexual Headache [52,66,67] & $\mathbf{4 5 9}$ &
\end{tabular}

*One case reported singing as a provocation of Thunderclap Headache [47].

haematoma as a retroclival haematoma), arterial dissection, venous sinus thrombosis, expanding or thrombosed berry aneurysm, venous thrombosis. Intravascular air was reported in isolated case reports only. It is possible that some of the cases of convexity or intraparenchymal haemorrhage were secondary to vasoconstrictive processes, but we were unable to confirm this from the published material.

Ischaemic stroke also features as an association of sudden and severe headache in cohort studies as well in individual case reports, but whether the infarction process is the cause of headache or whether

Table 5160 cases of infection associated sudden and severe headache, by study type

\begin{tabular}{|c|c|c|}
\hline Study type & Final diagnosis & $\mathrm{N}$ \\
\hline Cohort & Viral IIIness [31] & 41 \\
\hline Cohort & Rhinosinusitis $[27,31]$ & 36 \\
\hline Cohort & Aseptic meningitis $[17,27-29,69]$ & 27 \\
\hline Series & Aseptic meningitis [70] & 24 \\
\hline Cohort & Headache attributed to systemic viral infection [27] & 9 \\
\hline Case & Erve virus infection [71] & 7 \\
\hline Cohort & Bacterial meningitis $[27,31,69]$ & 4 \\
\hline Case & Erve virus infection and migraine [71] & 2 \\
\hline Case & *Acute Q-fever with cerebellar \& meningeal involvement [72] & 1 \\
\hline Case & *Bacterial meningitis secondary to a transethmoidal encephalocele [73] & 1 \\
\hline Case & *Dengue haemorrhagic fever [74] & 1 \\
\hline Case & Pneumococcal Meningitis, lower lobe pneumonia [75] & 1 \\
\hline Cohort & *Acute Cranial Herpes Zoster [27] & 1 \\
\hline Cohort & Herpes Encephalitis [28] & 1 \\
\hline Case & Erve Virus Infection and Sinusitis [71] & 1 \\
\hline Case & Persistent Primary Thunderclap Headache - related to Erve virus [76] & 1 \\
\hline Case & *Subarachnoid Haemorrhage due to Borrelia burgdorferi-associated vascultis [77] & 1 \\
\hline \multirow[t]{4}{*}{ Case } & Thunderclap headache secondary to complicated sinusitis [78] & 1 \\
\hline & Subtotal cohort & 119 \\
\hline & Subtotal case series & 24 \\
\hline & Subtotal case reports & 17 \\
\hline
\end{tabular}


Table 6398 cases of neurovascular thunderclap headaches, excluding vasoconstriction

\begin{tabular}{|c|c|c|}
\hline Study type & Final diagnosis & $\mathrm{N}$ \\
\hline & Intravascular Air ( $\mathrm{N}=2$ ) & \\
\hline Case & *Air embolus [79] & \\
\hline \multirow[t]{2}{*}{ Case } & *Cerebral Venous Air Embolism following dental implanation [80] & 1 \\
\hline & Aneurysm ( $N=18)$ & \\
\hline Cohort & Unruptured Intracranial [27] & \\
\hline Cohort & Giant Aneurysm [28] & 1 \\
\hline Series & Unruptured Intracranial Aneurysm [35] & 7 \\
\hline Case & Unruptured Intracranial Aneurysm [48,81-83] & 4 \\
\hline Case & *Recurrence and growth of previously coiled aneurysm [84] & 2 \\
\hline Case & ${ }^{*}$ Carotid artery aneurysm \& carotid cavernous fistula [85] & \\
\hline Case & Unruptured Intracranial Aneurysm with Thrombosis [86] & \\
\hline Case & Carotid artery aneurysm thrombosis [87] & \\
\hline
\end{tabular}

Cohort $\quad$ Carotid Artery Dissection [27]

Series $\quad$ Vertebral Artery Dissection [88] $\quad 18$

Case Carotid Artery Dissection [89-91] 4

Case $\quad$ *Basilar Artery Dissection (coital) [92] 2

Case $\quad$ *Vertebral Artery Dissection with Reversible Cerebral Vasoconstriction Syndrome and RPLS [93] 1

Case

Case

Case

Case

Case

*Vertebral Artery Dissection, Subarachnoid Haemorrhage and PRES [93] 1

Vertebral and Carotid Artery Dissection [94] 1

*Vertebral Artery Dissection with Cerebellar Infarction [95] 1

*Middle Cerebral Artery dissection [96] 1

Vertebral Artery Dissection [97] 1

Intracranial Haemorrhage $(\mathrm{N}=\mathbf{2 5 2})$

Cohort Subarachnoid Haemorrhage [17,27-29,31,69] 206

Cohort Intracerebral Haemorrhage [17,28,29] 9

Cohort Intracranial Haemorrhage [31] 1

Cohort Subdural Haematoma [31] $\quad$ S

Cohort Haemorrhagic malignant glioma [28] $\quad$ H

Series $\quad$ Pre-truncal nonaneurysmal subarachnoid haemorrhage [98] 18

Case Convexity Subarachnoid Haemorrhage [99] 3

Case $\quad$ *Right convexity Subarachnoid Haemorrhage associated with right MCA atherosclerosis [99]

Case $\quad$ *Simultaneous multiple brain haemorrhages associated with migraine, \& cerebral amyloid angiopathy [100] 1

Case Spontaneous Retroclival Haematoma [101] $\quad 1$

Case $\quad{ }^{*}$ Convexity Subarachnoid Haemorrhage with multiple brain abscesses [102] 1

Case $\quad$ * Convexity Subarachnoid Haemorrhage with postpartum posterior encephalopathy [102] 1

Case Convexity Subarachnoid Haemorrhage with vascultitis [102] 1

Case $\quad$ *Trigeminal Haemorrhagic Inflammatory pseudotumour [103] 1

Case $\quad$ Left thalamic haematoma [104] 1

Case $\quad$ *Subarachnoid Haemorrhage secondary to ecchordosis physaliphora [105] 1

Case *Headache secondary to diffuse subarachnoid density (blood and iohexol) on CT [106] $\quad$ * $\quad$ *

Case Cerebellar Haemorrhage secondary to cerebellar angioma [107] 1

Case $\quad$ Temporal Lobe Haematoma [107] 1

Case Diffuse vasospasm after pretruncal nonaneurysmal subarachnoid haemorrhage [108] $\quad$ _ 
Table 6398 cases of neurovascular thunderclap headaches, excluding vasoconstriction (Continued)

\begin{tabular}{|c|c|c|}
\hline & Idiopathic $(\mathrm{N}=4)$ & \\
\hline Cohort & Arteriovenous Malformation [28] & \\
\hline Case & Posterior reversible leucoencephalopathy [109] & \\
\hline Case & Thrombotic thrombocytopenia [110] & \\
\hline \multirow[t]{2}{*}{ Case } & Hypertensive Encephalopathy [111] & \\
\hline & Non-Haemorrhagic Stroke or Cerebral Infarction or Ischaemia $(N=66)$ & \\
\hline Cohort & Stroke or Cerebral Infarction or Ischaemia [17,27-29,31] & 56 \\
\hline Case & Ischaemic Cerebrovascular Disease [107] & 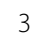 \\
\hline Case & PICA Territory Infarction [112] & \\
\hline Case & Embolic Cerebellar Infarcts [113] & \\
\hline Case & Ischaemic stroke [114] & \\
\hline Case & Thunderclap Headache secondary to right semiovale infarction [115] & \\
\hline Case & Posterior cerebral artery infarction [116] & \\
\hline Case & Vertebral Artery Dissection with left lateral medullary infarction [117] & \\
\hline \multirow[t]{2}{*}{ Case } & ${ }^{*}$ Occlusion of the posterior communicating artery [118] & \\
\hline & Inflammatory Arteriopathy $(\mathrm{N}=6)$ & \\
\hline Case & Cerebral Angiitis $[119,120]$ & \\
\hline Case & *Vogt-Koyanagi-Harada Disease $[121,122]$ & \\
\hline \multirow[t]{2}{*}{ Case } & Subarachnoid Haemorrhage secondary to Inflammatory Vasculitis [123] & \\
\hline & Cerebral Venous Sinus Thrombosis $(\mathrm{N}=19)$ & \\
\hline Cohort & Cerebral Venous Sinus Thrombosis $[17,27,29]$ & 3 \\
\hline Case & Cerebral Venous Sinus Thrombosis [124-129] & 14 \\
\hline Case & Cerebral Venous Sinus Thrombosis with Intracerebral Haemorrhage [130] & 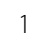 \\
\hline Case & ${ }^{*}$ Cerebral Venous Sinus Thrombosis with secondary Hydrocephalus [131] & 1 \\
\hline
\end{tabular}

*Specific Aetiologies not mentioned in Academic reviews.

the headache was a manifestation of an occult vasculopathy, such as a vasoconstriction syndrome, remains uncertain (Table 6).

We identified 234 cases where vasoconstriction was a plausible or proven mechanism for headache. It was not always reported whether vasoconstriction was reversible, as this would require reporting of normal follow-up imaging. Vasoconstriction syndromes could be associated with a range of factors, specifically post-partum states [151], cocaine use [177], spontaneous intracranial hypotension [171], sickle-cell disease [185] and posterior leucoencephalopathy [160] (Table 7).

\section{Non-vascular, neurological causes}

$5 \%$ of published cases had a non-vascular, neurological aetiology, including intracranial hypotension [189], pneumocephalus [190], pituitary apoplexy [33], other cerebral neoplasms [191], including colloid cyst of the third ventricle [192]. Psychological presentations [193] and post-seizure headache [27] were amongst reported causes of sudden and severe headache (Table 8).

\section{Systemic illnesses}

A small number of cases (13 in total) were reported in association with non-neurological, non-cerebrovascular causes, the most prominent of which was acute myocardial infarction (Table 9).

\section{Comparison of causes identified in academic reviews versus systematic review}

Of the causes not reported in academic reviews, and identified in our review, intracranial air, either intravascular or spontaneous pneumocephalus was the most frequently omitted cause (Table 8).

Case reports did identify potentially serious isolated causes of sudden and severe headache, specifically Aortic Dissection and Myocardial Infarction. Ecchordosis Physaliphora is a notochord related remnant which can cause intracranial haemorrhage, which was fatal in a published case report [105]. Psychologically mediated causes of Sudden and Severe Headache were also identified (Transitional Interpersonality Disorder and Hyperventilation Attacks). Perhaps surprisingly, there was no 
Table 7234 Cases of thunderclap headache with vasoconstriction

\begin{tabular}{|c|c|c|}
\hline & Vasoconstriction syndromes $(\mathrm{N}=\mathbf{2 3 4})$ & \\
\hline Series & Reversible Cerebral Vasoconstriction Syndrome $[132,133]$ & 95 \\
\hline Series & Recurrent primary thunderclap headache and benign CNS angiopathy [134] & 5 \\
\hline Case & Reversible Cerebral Vasoconstriction Syndrome [135-149] & 1 \\
\hline Case & Reversible Cerebral Vasoconstriction Syndrome associated with Subarachnoid Haemorrhage [150] & \\
\hline Case & Postpartum Angiopathy with Reversible Posterior Leucoencephalopathy [151] & \\
\hline Case & Thunderclap headache with segmental intracerebral vasoconstriction [152] & \\
\hline Case & Cerebral Vasoconstriction Syndrome (Call-Fleming Syndrome) with ischaemic stroke [153] & \\
\hline Case & Reversible cerebral vasoconstriction syndrome with Subarachnoid Haemorrhage [123] & \\
\hline Case & Thunderclap headache with diffuse, multifocal, segmental, and reversible vasospasm [154] & \\
\hline Case & *Bilateral parietooccipital convexity Subarachnoid Haemorrhage with vasoconstriction [99] & \\
\hline Case & *Left cerebral convexity Subarachnoid Haemorrhage with vasoconstriction [99] & \\
\hline Case & Complicated Migraine associated with orgasmic cephalgia [155] & \\
\hline Case & severe migraine variant with segmental cerebral arterial narrowing and watershed infarction [156] & \\
\hline Case & Reversible Cerebral Vasoconstriction Syndrome with Cerebral Infarction [157] & \\
\hline Case & Recurrent thunderclap headache with reversible intracerebral vasospasm and stroke [158] & \\
\hline Case & Diffuse Cerebral Vasospasm - possibly ergotamine associated [159] & \\
\hline Case & Reversible Cerebral Vasoconstriction Syndrome with posterior leukoencephalopathy syndrome [160] & \\
\hline Case & Bathing headache with diffuse vasospasm with posterior leukoencephalopathy [36] & \\
\hline Case & Delayed Eclampsia with associated vasospasm [161] & \\
\hline Case & Cerebral Vasoconstriction with right MCA cerebral infarction [162] & \\
\hline Case & Thunderclap headache with posterior leukoencephalopathy syndrome [163] & \\
\hline Case & *Orgasmic headache with Transient Basilar Artery Vasospasm [164] & \\
\hline Case & Orgasmic headache and cerebral vasospasm [165] & \\
\hline Case & Thunderclap headache with cerebral vasospasm [166] & \\
\hline Case & Call-Fleming PostPartum Angiopathy in the Puerperium [167] & \\
\hline Case & Posterior leucoencephalopathy associated with vasospasm [168] & \\
\hline Case & Nonaneurysmal subarachnoid haemorrhage with secondary cerebral vasoconstriction [169] & \\
\hline Case & Call-Fleming syndrome [170] & \\
\hline Case & *Reversible Cerebral Vasoconstriction Syndrome following Spontaneous Intracranial Hypotension [171] & \\
\hline Case & Call-Fleming Syndrome [172] & \\
\hline Case & Left frontal intracerebral haemorrhage secondary to benign angiopathy of the central nervous system [173] & \\
\hline Case & Reversible Cerebral Vasoconstriction Syndrome [135] & \\
\hline Case & Cerebral Vasoconstriction Syndrome with Subarachnoid Haemorrhage [174] & \\
\hline Case & Convexity Subarachnoid Haemorrhage, with sulcal haematoma secondary to cerebral vasoconstriction [174] & \\
\hline Case & Reversible Cerebral Vasoconstriction Syndrome causing right putaminal haemorrhage [175] & \\
\hline Case & Unruptured Intracranial Aneurysm with vasoconstriction [176] & \\
\hline Case & Cocaine related Neurovascular Headache [177] & \\
\hline Case & *Late onset eclampsia with cortical blindness [178] & \\
\hline Case & Reversible Cerebral Vasoconstriction Syndrome associated with orgasmic headache [179] & \\
\hline Case & *Tacrolimus Encephalopathy [180] & \\
\hline Case & Headache associated with Postpartum Cerebral Angiopathy [181] & \\
\hline Case & Reversible posterior leucoencephalopathy associated with minimal change disease [182] & \\
\hline Case & Post partum cerbral angiopathy (Call fleming syndrome) [183] & \\
\hline Case & Eclamptic subarachnoid haemorrhage secondary to Post-partum cerebral angiopathy [184] & \\
\hline
\end{tabular}


Table 7234 Cases of thunderclap headache with vasoconstriction (Continued)

\begin{tabular}{lll}
\hline Case & *Recurrent PRES in a patient with sickle cell disease [185] & 1 \\
Case & Ipsilateral reversible cerebral vasoconstriction after Carotid Endarterectomy [186] & 1 \\
Case & Benign exertional and sexual headache with arterial spasm [187] & 1 \\
Case & Reversible cerebral vasoconstriction Syndrome associated oxymetazoline nasal spray [188] & 1 \\
\hline
\end{tabular}

*Specific Aetiologies not mentioned in Academic reviews.

Table 8119 Neurological, non-vascular cases of thunderclap headache

\begin{tabular}{|c|c|c|}
\hline Study type & Final diagnosis & $\mathrm{N}$ of cases \\
\hline & Intracranial Air ( $\mathrm{N}=6)$ & \\
\hline Case & *Pneumocephalus associated with frontal pneumosinus dilatans [194] & \\
\hline Case & *Pneumocephalus [195-199] & \\
\hline 40 & CSF Pressure Disorders $(\mathrm{N}=40)$ & \\
\hline Cohort & Headache due to low CSF pressure [27] & 14 \\
\hline Cohort & Idiopathic Intracranial Hypertension [27] & \\
\hline Cohort & ${ }^{*}$ Cerebral Oedema $[17,29]$ & 2 \\
\hline Case & Spontaneous Intracranial Hypotension [79,189,200-206] & 16 \\
\hline Case & Third Ventricle Colloid Cyst $[192,207]$ & 2 \\
\hline Case & ${ }^{*}$ Adult aqueductal stenosis [208] & \\
\hline Case & Intracranial hypotension secondary to retained spinal needle [79] & \\
\hline Case & Intraventricular arachnoid cyst [209] & \\
\hline Case & Cerebellar tonsillar herniation [210] & \\
\hline Case & Hydrocephalus secondary to third ventricle dermoid cyst [211] & \\
\hline
\end{tabular}

3

Neuro-Inflammatory Disorders $(\mathrm{N}=3)$

Cohort

*HaNDL Syndrome [27]

Cohort

*Ocular Inflammatory Disorder [27]

Case

*Apoplectic headache secondary to Multiple Sclerosis [212]

Chemical Meningitis ( $\mathrm{N}=4)$

Case

*Rathke's cleft cyst [213,214]

${ }^{*}$ Ruptured spinal dermoid tumour [215]

Case

*Ruptured arachnoid cyst into subdural space [216]

Intracranial Neoplasm $(\mathrm{N}=7)$

Cohort

Neoplasm $[27,31,69]$

Case

*Nonhaemorrhagic Anaplastic Oligodendroglioma [191]

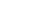


Table 913 Cases with systemic illness in association with sudden and severe headache

\begin{tabular}{lll}
\hline Study type & Final diagnosis & N \\
\hline Case & & $\mathbf{7}$ \\
Case & Acute Myocardial Infarction [26,227-232] & 8 \\
Case & Aortic Dissection [233-235] & 3 \\
Case & Thunderclap Headache Secondary to Phaeochromocytoma [236,237] & 2 \\
Case & Acute Puerpural headache \& hypertension [238] & 1 \\
Case & Acute Intracranial Hypertension due to Occlusion of the Brachiocephalic vein [239] & \\
Case & Coital Headaches induced by Amiodarone [240] & 1 \\
Case & Coital headache secondary to thyrotoxicosis (I[51]) & \\
Cohort & & \\
Cohort & Musculoskeletal [234] & \\
Cohort & Alcohol Induced Headache [234] & \\
Cohort & Analgesic Overuse Headache [234] & \\
Cohort & Arterial Hypertension [234] & \\
Cohort & Amphetamine Misuse [234] & \\
Cohort & Triptan overdose & 1 \\
\hline
\end{tabular}

publication of Munchausen's Syndrome as a cause of sudden and severe headache.

\section{Non-English articles}

The full text of a total of 29 non-English publications were examined once we had completed the main review of English Language publications - 27 case reports from 22 publications [241-263], and 599 cases from 8 case series [264-271]. The single large case series from Japan described 562 people with thunderclap headache, normal CT Brain and normal visually inspected CSF. Of these 562 people 52 berry aneurysms were identified at angiography, 46 of which went to surgery, 8 of which had evidence at surgery of recent haemorrhage, 4 of which had abnormal CSF cell count or protein levels [264,265].

There were 4 non-English language cohort studies [271-274], which did not identify any additional causes of abrupt, severe headache. In the 6 non-English academic review articles [20-25], ice-cream headache, exploding head syndrome and aortic coarctation were listed as potential causes of acute headache, although these causes were not identified in our own literature search, and exploding head syndrome was excluded as it is an intracranial noise rather than a headache.

Unique cases from non-English case report literature included Headache Associated with Sexual Activity associated with a Frontal Meningioma [246] or Intraventricular Arachnoid Cyst [244], Subarachnoid Haemorrhage secondary to Vertebral Artery Dissection [257], Convexity Subarachnoid Haemorrhage following Spinal Anaesthesia [249], Acute Hydrocephalus secondary to Chiari Malformation [259], and Pneumocephalus following inadvertent dural puncture at Epidural Anaesthestic [263].
4 cases of aneurysmal subarachnoid haemorrhage associated with normal CT Brain and normal appearing CSF (by visual inspection, not by spectrophotometry) were identified from a large case series from Japan [264,265]. The 4 non-English Language Cohort Studies did not identify causes that were not already identified from English language articles.

From the non-English academic reviews, Hypnic Headache, Cluster Headache, Exploding Head Syndrome, Ice-cream Headache and Aortic Coarctation were listed as causes of sudden and severe headache. It was not possible to get more clinical information on the published case of aortic coarctation which was included as part of a larger cohort.

\section{Discussion}

We present a comprehensive review of the literature on Sudden AND Severe Headache up to September 2009.

From our search, we estimate that we have identified 98\% of all published causes of Sudden AND Severe Headache in the English Literature.

The literature on sudden and severe headache has some significant weaknesses, yet allows us to make some interesting observations on this potentially serious symptom and how information is reported in medical literature.

Prospective, longitudinal studies of unselected cases are crucial for determining accurate frequencies of incidence or cause. The only estimate of population-based incidence is from Sweden, at 43 cases per 100,000 adults per annum, which was estimated from a sub-set of the population in their study [17]. This figure is important as it is the only one that can inform service planning for the assessment of sudden and severe headache across a large population. 
Our understanding of causes of sudden and severe headache is evolving, yet we do not have a precise knowledge of trends or causes of this symptom in a population over time. An emerging theme are the cerebral vasoconstriction syndromes which are attracting a lot more attention in the medical literature and since our literature review have been the subject of several major reviews [275,276], yet this cause was not described in any of the large cohort studies we found in our systematic review.

In cohort studies, where neurologists assigned diagnosis, headaches of unspecified cause, uncertain cause or a primary headache accounted for the majority of cases in unselected populations. This is contrary to hospital based clinical practice where a diagnosis of migraine, tensiontype headache or cluster headache would hardly ever be used in the context of an abrupt onset of severe headache. Sudden and severe headache which remains unexplained following appropriate investigation would normally be called Primary or Idiopathic Thunderclap Headache. Reasons for this large number of unexplained or uncertain headaches remain obscure.

Another seemingly important cause of headache in a population is cervicogenic headache, which was identified in about $4 \%$ of adults in the Vaga Study [277]. The cohort studies identified a small number of 'musculoskeletal' related headaches [31] and there was one case series of occipital neuralgia presenting acutely to hospital [34], but otherwise this common headache is unreported as causing sudden and severe headache, yet seems a plausible candidate for many of the 'uncertain' or 'unclassified' cases.

Intracranial Hypotension is an important cause which featured in both cohort and case-based studies - so is both common enough to see in practice, and its treatable nature makes it reportable.

An up to date population-based study could make an important contribution to our current knowledge of sudden and severe headache, specifically the true incidence and prognosis of vasoconstriction syndromes, and better assessment of the clinical features and prognosis of those with 'uncertain' or 'unclassifiable' headaches.

Cases identified from series are important, as they aggregate information on relatively low frequency conditions as a reference for other clinicians. However, they distort the overall frequency of causes of headaches in our review eg pituitary apoplexy was not reported in the major cohorts. Nonetheless, accumulating cases of specific sub-types can greatly inform clinical practice and generate research hypotheses. An example of this is Headache Associated with Sexual Activity where a recent case series from Taiwan has identified the Reversible Cerebral Vasoconstriction Syndrome in almost 2/3rds of cases [278].

By their nature, case reports will focus on the esoteric or unusual, but our review has highlighted some important associations including systemic conditions like Aortic Dissection [233,234,279,280], Cardiac Cephalalgia [26,227-229,231,232,281-283], Phaeochromocytoma [236,237], serious infections like Dengue Haemorrhagic Fever [74] and Q-Fever [72], as well as Erve Virus [68,71]. Rare vasculopathies such as Vogt-Kayanagi-Harada Disease [121,122], or cerebral vasculitis [119] do appear on the differential diagnosis. Another important presentation, identified in case reports only, was basilar artery dissection manifesting as a coital headache [92].

Cerebral vasculitis is commonly mentioned in discussions about sudden and severe headache, but in numeric terms, we only identified 6 cases of an 'inflammatory arteriopathy' compared to 234 cases of a likely vasoconstriction.

\section{Vasoconstriction syndromes}

There is evidence that many cases of otherwise unexplained Sudden AND Severe Headache, particularly coital headache, are actually due to Reversible Cerebral Vasoconstriction [278,284], and that pain is mediated by sympathetic innervated cerebral arteries. A recent systematic review of 214 cases of Reversible Cerebral Vasoconstriction Syndrome found 94\% cases presented with thunderclap headache, which was often recurrent [276]. Our review identified 234 cases where vasoconstriction was the likely mechanism of headache (Table 9). Of these 234 cases, 37 (16\%) had complications such as posterior leucoencephalopathy (11 cases, $5 \%$ ), ischaemic stroke (7 cases, $3 \%$ ) or haemorrhage (19 cases, $8 \%$ ).

It is interesting to observe that low CSF pressure states have been accompanied by reversible cerebral vasoconstriction on one [171] if not 2 occasions [135]. This raises the intriguing possibility that Lumbar Puncture may not always be advisable when investigating a Thunderclap Headache if cerebral vasoconstriction is present. However, there is insufficient data to guide clinical practice at present.

Our review still supports the concept that Vasoconstriction Syndromes are probably part of a spectrum of disorders with an isolated sudden and severe headache at one end and multiple headaches and serious neurovascular complications at the other [278,284].

\section{Publication bias}

One of our review's objectives was to identify all causes as a prelude to writing a management guideline for Thunderclap Headache, and we were aware of relevant academic review articles [3-9]. Our systematic review did identify additional causes of sudden AND severe headache, such as Aortic Dissection and Pneumocephalus that were not specifically mentioned in these review articles. This is not to say that academic reviewers had no knowledge of these cases, but may merely reflect editorial practice. In fact 2 academic reviews stated search criteria 
[3,18]. However, some causes of Thunderclap Headache are more commonly listed than others eg spontaneous retroclival haematoma, even when there has only ever been one solitary case published [101].

Our review collates a large number of published causes of sudden and severe headache and may serve as a benchmark for clinicians and researchers alike, as we estimate that our review may be $98 \%$ complete. Evidence based practice requires systematic critique of evidence, and our review is novel for applying this method to a list of causation. Medical lists are ubiquitous in medical education and clinical practice guidelines. The value of 'lists' is that information can be memorised and disseminated easily, but by being non-systematic they may perpetuate error as well as fact.

\section{Limitations of this review and subsequent publications}

Since the review completed, there have been some additional cases added to the medical literature, including spontaneous spinal epidural haematoma [285], and several more associations of the Reversible Cerebral Vasoconstriction Syndrome such as carotid glomus tumour [286] and Takayasu's Arteritis [287]. There has also been a major academic review on Thunderclap Headache published in 2013 [288] which did not identify additional cases to those mentioned in our own review [275]. We continue to monitor publications on thunderclap headache, but this paper will be limited to cases published by September 2009.

A potential criticism of this work is that we did not use the International Headache Society Classification of Headache Disorders. However, retrospective use of the criteria was not possible from the majority of published articles where criteria were not specified. If we had attempted to apply IHS criteria we may have created further error by assigning a classification without full information. Nonetheless, the objective of our review was to try and determine the full range of potential diagnoses that might emerge in someone who has presented for the assessment of a sudden and severe headache. We feel we have been as comprehensive and accurate as the published literature allows.

\section{Using this data in clinical practice}

In clinical practice, the differential diagnosis is central to organising diagnostic tests. The diagnostic evaluation is a screening process for target diseases. We can now argue that in a patient presenting with a sudden and severe headache that we have now created a definitive list of possible causes for sudden and severe headache i.e. we have quantified the possible diagnoses that have made it to the published literature, and that this list is arguably 98\% complete.

The cohort studies provide the relative frequency with which target diseases might occur in practice, and it is common sense to look for these in the first instance. The case series and case reports identify cases that illustrate unusual mechanisms for sudden and severe headache - for example myocardial infarction or pituitary apoplexy.

Clinicians looking to manage people with sudden and severe headache should now consider this list as a definitive reference, and if they think they identified an additional cause they can rapidly verify whether their case is unique, and therefore meriting publication.

\section{Future research}

As our paper has shown that there is a difference between the causes of sudden and severe headache published in academic reviews and those identified from a systematic review, it would be important to maintain this list on an ongoing basis as a reference point for clinicians and researchers.

Amongst potential problems in current medical publishing practice is that articles run out of date, and systematic reviews need updating. At present, the Cochrane Collaboration do not provide for systematic reviews of causation, yet this information is important in clinical practice when trying to reach a diagnosis.

There is also a need to do an up to date prospective, population based study of sudden and severe headache with a specific emphasis on identifying the frequency of vasoconstriction syndromes, the long term prognosis of cases in whom aneurysmal subarachnoid haemorrhage is excluded, and examining cases where a clinical diagnosis remains elusive, even after examination by a neurologist.

\section{Conclusions}

This paper presents what we regard as a definitive list of associations of Sudden and Severe Headache. This list is important as it demonstrates that the differential diagnosis of sudden and severe headache is substantial. Our review confirms that a wide range of diseases and provoking circumstances are associated with sudden and severe headache, specifically, haemorrhage, thrombosis, dissection, arterial expansion, extremes of intracranial pressure, infection, inflammation and even intracranial air. In large unselected cohorts the majority of cases are assigned a primary headache diagnosis or have a cause of headache that does not meet any specific diagnostic criteria.

New cases of sudden and severe headache associated with conditions which are not represented in our list should be considered for publication in the medical literature as novel causes.

\section{Competing interests}

$\mathrm{RF}$ has received unrestricted educational grants to fund attendance at European Neurological Society meeting in Athens 2004 (value <1000GBP), The International Headache Society Meeting in Stockholm 2007 (value <1000GBP) 
and The American Headache Society Meeting Boston June 2008 (value $<2000$ GBP), The EHMTIC meeting London 2012 (value <1000GBP) from Janssen-Cilag and Allergan pharmaceutical companies. The Neurology Department in which RF practices received an unrestricted educational grant from Cyberonics for an economic analysis of vagus nerve stimulators in 2007 (value 7000GBP). RF has received an honorarium for contributions at an educational meeting sponsored by Allergan in Dublin November 2013 (1065GBP). RF runs a website called severe-headache-expert.com which earns income from advertising. HN no conflicts of interest. ED no conflicts of interest.

\section{Authors' contributions}

RF initiated and designed the review, screened the articles, assisted with data abstraction, data analysis, co-wrote and edited and approved the final manuscript, and is ultimately accountable for this work. HN designed the systematic review and obtained articles from external sources. ED abstracted data from identified articles, summarized and analysed data, wrote initial version of manuscript and approved final version for submission. All authors read and approved the final manuscript.

\section{Funding source}

The Southern HSC Trust awarded a grant of 1000GBP towards publication costs.

Received: 17 April 2014 Accepted: 3 June 2014

Published: 14 August 2014

\section{References}

1. Craig JJ, Patterson VH (1997) Headaches in the accident and emergency department. Br J Hosp Med 57:202-206

2. Edlow JA, Caplan LR (2000) Avoiding pitfalls in the diagnosis of subarachnoid hemorrhage. [see comment]. N Engl J Med 342:29-36

3. Schwedt TJ, Matharu MS, Dodick DW (2006) Thunderclap headache. Lancet Neurol 5:621-631

4. Matharu MS, Schwedt TJ, Dodick DW (2007) Thunderclap headache: an approach to a neurologic emergency. Curr Neurol Neurosci Rep 7:101-109

5. Schwedt TJ (2007) Clinical spectrum of thunderclap headache. Expert Rev Neurother 7:1135-1144

6. Dodick DW (2002) Thunderclap headache. J Neurol Neurosurg Psychiatry 72:6-11

7. Dodick DW (2002) Thunderclap headache. Headache 42:309-315

8. Davenport R (2002) Acute headache in the emergency department. [see comment]. J Neurol Neurosurg Psychiatry 72(Suppl 2):ii33-ii37

9. Davenport R (2004) Diagnosing acute headache. [see comment]. Clin Med 4:108-112

10. National Library of Medicine (2013) Medical Subject Headings Expanded Database. [27th December 2013]. Available from: http://www.nlm.nih.gov/ cgi/mesh/2014/MB_cgi?mode=\&index=23330\&view=expanded

11. Pearce JM (1988) Exploding head syndrome. Lancet 2(8605):270-271

12. Raskin NH, Schwartz RK (1980) Icepick-like pain. Neurology 30(2):203-205

13. Gronseth G, Cruccu G, Alksne J, Argoff C, Brainin M, Burchiel K, Nurmikko T, Zakrzewska JM, et al. (2008) Practice parameter: the diagnostic evaluation and treatment of trigeminal neuralgia (an evidence-based review): report of the Quality Standards Subcommittee of the American Academy of Neurology and the European Federation of Neurological Societies. Neurology 71(15):1183-1190

14. Silberstein SD, Olesen J, Bousser MG, Diener HC, Dodick DW, First M, Goadsby PJ, Gobel H, Lainez MJ, Lance JW, Lipton RB, Nappi G, Sakai F, Schoenen J, Steiner TJ (2005) The International Classification of Headache Disorders, 2nd Edition (ICHD-II)-revision of criteria for 8.2 Medicationoveruse headache. Cephalalgia 25(6):460-465

15. Google (2013) Google Translate. [27th December 2013]. Available from: http://translate.google.com/\#auto/en/

16. Hook EB, Regal RR (1995) Capture-recapture methods in epidemiology: methods and limitations. Epidemiol Rev 17(2):243-264

17. Landtblom A-M, Fridriksson S, Boivie J, Hillman J, Johansson G, Johansson I (2002) Sudden onset headache: a prospective study of features, incidence and causes. Cephalalgia 22:354-360

18. Linn FHH, Wijdicks EFM (2002) Causes and management of thunderclap headache: a comprehensive review. Neurologist 8:279-289
19. Moussouttas M, Mayer SA (2008) Thunderclap headache with normal CT and lumbar puncture: further investigations are unnecessary: against. [comment]. Stroke 39:1394-1395

20. Boivie J (1991) Thunderclap headache-scary and alarming. Lakartidningen 88(25):2312-2314

21. Ducros A (2005) Thunderclap headache. Rev Neurol (Paris) 16(6-7):713-715

22. Kerkhoff H, Wijdicks EF, van Gijn J (1989) Headache like a thunderclap in a clear sky: subarachnoid bleeding or harmless disorder? Ned Tijdschr Geneeskd 133:1881-1883

23. Sturzenegger M (1993) Acute headache. Schweiz Med Wochenschr 123:789-799

24. Mumenthaler M (1997) The dangerous headache. Ther Umsch 54:79-82

25. Gauvrit JY, Leclerc X, Moulin T, Oppenheim C, Savage J, Pruvo JP, Meder JF (2004) Headaches in the emergency context. J Neuroradiol 31:262-270

26. Wang WW, Lin C-S (2008) Headache angina. Am J Emerg Med 26:387.e1-e2

27. Bo SH, Davidsen EM, Gulbrandsen P, Dietrichs E (2008) Acute headache: a prospective diagnostic work-up of patients admitted to a general hospital. Eur J Neurol 15:1293-1299

28. Linn FH, Wijdicks EF, van der Graaf $Y$, Weerdesteyn-van V, Bartelds Al, van Gijn J (1994) Prospective study of sentinel headache in aneurysmal subarachnoid haemorrhage. Lancet 344:590-593

29. Ahmad A, Khan P, Ahmad K, Syed A (2008) Diagnostic outcome of patients presenting with severe thunderclap headache at Saidu Teaching Hospital. Pakistan J Med Sci 24:575-580

30. Singhal AB (2004) Cerebral vasoconstriction syndromes. Topics in Stroke Rehabilitation 11:1-6

31. Perry JJ, Stiell IG, Wells GA, Mortensen M, Lesiuk H, Sivilotti M, Kapur A (2005) Attitudes and judgment of emergency physicians in the management of patients with acute headache. Acad Emerg Med 12:33-37

32. Wang SJ, Fuh JL, Wu ZA, Chen SP, Lirng JF (2008) Bath-related thunderclap headache: a study of 21 consecutive patients. Cephalalgia 28:524-530

33. Dodick DW, Wijdicks EF (1998) Pituitary apoplexy presenting as a thunderclap headache. Neurology 50:1510-1511

34. Pascual-Leone A, Pascual-Leone P (1992) Occipital neuralgia: another benign cause of "thunderclap headache". J Neurol Neurosurg Psychiatry 55:411

35. Raps EC, Rogers JD, Galetta SL, Solomon RA, Lennihan L, Klebanoff LM, Fink ME (1993) The clinical spectrum of unruptured intracranial aneurysms. [see comment]. Arch Neurol 50:265-268

36. Liao YC, Fuh JL, Lirng JF, Lu SR, Wu ZA, Wang SJ (2003) Bathing headache: a variant of idiopathic thunderclap headache. Cephalalgia 23(9):854-859

37. Mak W, Tsang KL, Tsoi TH, Au Yeung KM, Chan KH, Cheng TS, Cheung TFR, Ho SL (2005) Bath-related headache. Cephalalgia 25:191-198

38. Negoro K, Morimatsu M, Ikuta N, Nogaki H (2000) Benign hot bath-related headache. Headache 40:173-175

39. Rossi P, Nappi G (2006) Bath-related headache: the first European case Cephalalgia 26:1485-1486

40. Tanaka M, Okamoto K (2007) Bath-related headache: a case report Cephalalgia 27:563-565

41. Ibbotson SH (1987) Weight-lifter's headache. Br J Sports Med 21:138

42. Powell B (1982) Weight lifter's cephalgia. Ann Emerg Med 11:449-451

43. Imperato J, Burstein J, Edlow JA (2003) Benign exertional headache. Ann Emerg Med 41:98-103

44. Nassar L, Albano J, Padron D (1999) Exertional headache in a collegiate gymnast. Clin J Sport Med 9:182-183

45. Massey EW (1982) Effort headache in runners. Headache 22:99-100

46. Kim JS (1992) Swimming headache followed by exertional and coital headaches. J Korean Med Sci 7:276-279

47. Kim YI, Lee SJ, Lee KS, Park JW, Kim JS (2008) Recurrent thunderclap headache triggered by singing. Eur J Neurol 15:e116-e117

48. Clarke C, Shepherd D, Chisti K, Victoratos G (1988) Thunderclap headache. Lancet 2:625

49. Lu S, Liao Y, Fuh J, Lirng J-F, Wang S-J (2004) Nimodipine for treatment of primary thunderclap headache. Neurology 62:1414-1416

50. Markus HS (1991) A prospective follow up of thunderclap headache mimicking subarachnoid haemorrhage. J Neurol Neurosurg Psychiatry 54:1117-1118

51. Lance JW (1974) Headaches occurring during sexual intercourse. Proc Aust Assoc Neurol 11:57-60

52. Katchen MS (1990) Exertional headaches with multiple triggers. Aviat Space Environ Med 61:49-51

53. Frese A, Rahmann A, Gregor N, Biehl K, Husstedt IW, Evers S (2007) Headache associated with sexual activity: prognosis and treatment options. Cephalalgia 27:1265-1270 
54. Porter M, Jankovic J (1981) Benign coital cephalalgia. Differential diagnosis and treatment. Arch Neurol 38:710-712

55. Kim H-J, Seo S-Y (2008) Recurrent emotion-triggered headache following primary headache associated with sexual activity. J Neurol Sci 273:142-143

56. Anand KS, Dhikav V (2009) Primary headache associated with sexual activity. Singapore Med J 50(5):e176-e177

57. Johns DR (1986) Benign sexual headache within a family. Arch Neurol 43:1158-1160

58. Lewis GN (1976) Orgasm headaches. J Indiana State Med Assoc 69:785-788

59. Martin EA (1974) Headache during sexual intercourse (coital cephalalgia). A report on six cases. Ir J Med Sci 143:342-345

60. Martinez JM, Roig C, Arboix A (1988) Complicated coital cephalalgia. Three cases with benign evolution. Cephalalgia 8:265-268

61. Nutt NR (1977) Sexually induced headaches. Br Med J 1:1664

62. Paulson GW, Klawans HL, Jr (1974) Benign orgasmic cephalgia. Headache 13(4):181-187

63. Selekler M, Kutlu A, Dundar G (2009) Orgasmic headache responsive to greater occipital nerve blockade. Headache 49:130-131

64. Ostergaard JR, Kraft M (1992) Benign coital headache. [see comment]. Cephalalgia 12:353-355

65. Larner AJ (2006) Late presentation of primary headache associated with sexual activity: is non-invasive angiography worthwhile? J Headache Pain 7:139-140

66. Edis RH, Silbert PL (1988) Sequential benign sexual headache and exertional headache. Lancet 1:993

67. Heckmann JG, Hilz MJ, Muck-Weymann M, Neundorfer B (1997) Benign exertional headache/benign sexual headache: a disorder of myogenic cerebrovascular autoregulation? Headache 37:597-598

68. Woessner R, Grauer MT, Langenbach J, Dobler G, Kroeger J, Mielke HG, Mueller P, Haass A, Treib J (2000) The Erve virus: possible mode of transmission and reservoir. Infection 28:164-166

69. Lledo A, Calandre L, Martinez-Menendez B, Perez-Sempere A, Portera-Sanchez A (1994) Acute headache of recent onset and subarachnoid hemorrhage: a prospective study. [see comment]. Headache 34:172-174

70. Lamonte M, Silberstein SD, Marcelis JF (1995) Headache associated with aseptic meningitis. Headache 35:520-526

71. Treib J, Dobler G, Haass A, von Blohn W, Strittmatter M, Pindur, Froesner GG, Schimrigk K (1998) Thunderclap headache caused by Erve virus? Neurology 50:509-511

72. Anonymous (1996) Case records of the Massachusetts General Hospital. Weekly clinicopathological exercises. Case 38-1996. An 18-year-old man with severe headache, pleocytosis, and ataxia. N Engl J Med 335:1829-1834

73. Schwartz MD, Shaw GJ (2002) Bacterial meningitis secondary to a transethmoidal encephalocele presenting to the emergency department. J Emerg Med 23(2):171-174

74. Basilio-de-Oliveira CA, Aguiar GR, Baldanza MS, Barth OM, Eyer-Silva WA, Paes MV (2005) Pathologic study of a fatal case of dengue-3 virus infection in Rio de Janeiro, Brazil. Braz J Infect Dis 9:341-347

75. Hosley C, Ward T (2008) Teaching case-headache in the emergency room: a review. Headache 48:988-990

76. Garza I, Black DF (2006) Persistent primary thunderclap headacheresponsive to gabapentin. J Headache Pain 7:419-421

77. Jacobi C, Schwark C, Kress B, Hug A, Storch-Hagenlocher B, Schwaninger M (2006) Subarachnoid hemorrhage due to Borrelia burgdorferi-associated vasculitis. Eur J Neurol 13:536-538

78. McGeeney BE, Barest G, Grillone G (2006) Thunderclap headache from complicated sinusitis. Headache 46:517-520

79. Chalaupka F, Caneve G, Mauri M, Zaiotti G (2007) Thunderclap headache caused by minimally invasive medical procedures: description of 2 cases. Headache 47:293-295

80. Botez SA (2007) Headache and cerebral venous air embolism. Neurology 68:19

81. Hughes RL (1992) Identification and treatment of cerebral aneurysms after sentinel headache. Neurology 42:1118-1119

82. Witham TF, Kaufmann AM (2000) Unruptured cerebral aneurysm producing a thunderclap headache. Am J Emerg Med 18:88-90

83. Markwalder TM, Meienberg O (1983) Acute painful cavernous sinus syndrome in unruptured intracavernous aneurysms of the internal carotid artery. Possible pathogenetic mechanisms. J Clin Neuroophthalmol 3:31-35

84. Byrum E, McGregor J, Christiforidis G (2009) Thunderclap headache without subarachnoid hemorrhage associated with regrowth of previously coil-occluded aneurysms. Am J Neuroradiol 30:1059-1061
85. Svenson J, Cowen D, Rogers A (1997) Headache in the emergency department: importance of history in identifying secondary etiologies. J Emerg Med 15:617-621

86. Anonymous (2002) Aneurysmal "thunderclap" headache without subarachnoid hemorrhage. Headache 42(1):82

87. Locatelli M, Spagnoli D, Caroli M, Isalberti M, Branca V, Gaini SM, Lania A (2008) A potential catastrophic trap: an unusually presenting sellar lesion. Eur J Neurol 15:98-101

88. Shibata T, Kubo M, Kuwayama N, Hirashima Y, Endo S (2006) Warning headache of subarachnoid hemorrhage and infarction due to vertebrobasilar artery dissection. Clin J Pain 22:193-196

89. Biousse V, Woimant F, Amarenco P, Touboul PJ, Bousser MG (1992) Pain as the only manifestation of internal carotid artery dissection. Cephalalgia 12:314-317

90. Cox LK, Bertorini T, Laster RE, Jr (1991) Headaches due to spontaneous internal carotid artery dissection magnetic resonance imaging evaluation and follow up. Headache 31:12-16

91. Fisher CM (1982) The headache and pain of spontaneous carotid dissection. Headache 22:60-65

92. Joo IS, Lee JS (2005) Dissecting aneurysm of the basilar artery as a cause of orgasmic headache. Headache 45:956-959

93. Arnold M, Camus-Jacqmin M, Stapf C, Ducros A, Viswanathan A, Berthet K, Bousser MG (2008) Postpartum cervicocephalic artery dissection. Stroke 39:2377-2379

94. Buyle M, Engelborghs S, Kunnen J, De Deyn PP (2001) Headache as only symptom in multiple cervical artery dissection. Headache 41:509-511

95. Gates J, Hartnell GG, Quintas J (1997) Young adult with "worst ever headache" following mild trauma. Acad Radiol 4:312-313

96. Szatmary Z, Boukobza M, Vahedi K, Stapf C, Houdart E, Bousser MG (2006) Orgasmic headache and middle cerebral artery dissection. J Neurol Neurosurg Psychiatry 77:693-694

97. Price L, Parghi C, Khan R (2007) Thunderclap headache-and a tender neck. Lancet 370:1974

98. Wijdicks EF, Schievink WI, Miller GM (1998) Pretruncal nonaneurysmal subarachnoid hemorrhage. Mayo Clin Proc 73:745-752

99. Refai D, Botros JA, Strom RG, Derdeyn CP, Sharma A, Zipfel GJ (2008) Spontaneous isolated convexity subarachnoid hemorrhage: presentation, radiological findings, differential diagnosis, and clinical course. J Neurosurg 109:1034-1041

100. Nakamura K, Saku Y, Ibayashi S, Fujishima M (1997) Simultaneous multiple brain hemorrhage associated with migraine: a case report. Angiology 48:551-555

101. Schievink WI, Thompson RC, Loh CT, Maya MM (2001) Spontaneous retroclival hematoma presenting as a thunderclap headache. Case report Journal of Neurosurgery 95:522-524

102. Spitzer C, Mull M, Rohde V, Kosinski CM (2005) Non-traumatic cortical subarachnoid haemorrhage: diagnostic work-up and aetiological background. Neuroradiology 47:525-531

103. Jung T-Y, Jung S, Lee M-C, Moon K-S, Kim I-Y, Kang S-S, Kim SH (2006) Hemorrhagic intracranial inflammatory pseudotumor originating from the trigeminal nerve: a case report. Journal of Neuro Oncology 76:139-142

104. Alvarez-Cermeno JC, Martinez-Castrillo JC, Gobernado JM (1988) Sudden headache associated with unilateral asterixis. Headache 28:352-353

105. Fracasso T, Brinkmann B, Paulus W (2008) Sudden death due to subarachnoid bleeding from ecchordosis physaliphora. Int J Legal Med 122:225-227

106. Jones LK, Flemming KD (2005) Headache and diffuse subarachnoid hyperdensity on head CT following thoracic epidural blood patch. Headache 45:951-953

107. Luda E, Comitangelo R, Sicuro L (1995) The symptom of headache in emergency departments. The experience of a neurology emergency department. Ital J Neurol Sci 16:295-301

108. Schievink WI, Wijdicks EF, Spetzler RF (2000) Diffuse vasospasm after pretruncal nonaneurysmal subarachnoid hemorrhage. AJNR Am J Neuroradiol 21:521-523

109. Edwards MJ, Walker R, Vinnicombe S, Barlow C, MacCallum P, Foran JM (2001) Reversible posterior leukoencephalopathy syndrome following CHOP chemotherapy for diffuse large B-cell lymphoma. Ann Oncol 12:1327-1329

110. Bridgman J, Witting M (1996) Thrombotic thrombocytopenic purpura presenting as a sudden headache with focal neurologic findings. Ann Emerg Med 27:95-97 
111. Tang-Wai DF, Phan TG, Wijdicks EF (2001) Hypertensive encephalopathy presenting with thunderclap headache. Headache 41:198-200

112. SuttonBrown M, Morrish W, Zochodne DW (2006) Recurrent coital 'thunderclap' headache associated with ischaemic stroke. Cephalalgia 26:1028-1030

113. Schwedt TJ, Dodick DW (2006) Thunderclap stroke: embolic cerebellar infarcts presenting as thunderclap headache. Headache 46:520-522

114. Annic A, Lucas C (2007) Ischemic stroke revealed by a thunderclap headache: contribution of diffusion-weighted mri sequences. Rev Neurol 163:599-601

115. Edvardsson BA, Persson S (2009) Cerebral infarct presenting with thunderclap headache. J Headache Pain 10:207-209

116. Alvaro LC, Iriondo I, Villaverde FJ (2002) Sexual headache and stroke in a heavy cannabis smoker. Headache 42:224-226

117. de Sousa JE, Halfon MJ, Bonardo P, Reisin RC, Fernandez Pardal MM (2005) Different pain patterns in patients with vertebral artery dissections. Neurology 64:925-926

118. Kawanishi M, Sakaguchi I, Miyake H (2003) Occlusion of the posterior communicating artery mimicking cerebral aneurysm: case report. Neurol Res 25:543-545

119. Crane R, Kerr LD, Spiera H (1991) Clinical analysis of isolated angiitis of the central nervous system. A report of 11 cases. [see comment]. Arch Intern Med 151:2290-2294

120. Cupps TR, Moore PM, Fauci AS (1983) Isolated angiitis of the central nervous system. Prospective diagnostic and therapeutic experience. Am J Med 74(1):97-105

121. Cho JH, Ahn JY, Byeon SH, Huh JS (2008) Thunderclap headache as initial manifestation of Vogt-Koyanagi-Harada disease. Headache 48:153-155

122. Tavsanli M, Uluduz D, Saip S, Kendiroglu G (2008) Vogt-Koyanagi-Harada disease: headache as an initial manifestation. J Headache Pain 9(4):255-256

123. Santos E, Zhang Y, Wilkins A, Renowden S, Scolding N (2009) Reversible cerebral vasoconstriction syndrome presenting with haemorrhage. J Neurol Sci 276:189-192

124. Widjaja E, Romanowski CAJ, Sinanan AR, Hodgson TJ, Griffiths PD (2003) Thunderclap headache: presentation of intracranial sinus thrombosis? Clin Radiol 58:648-652

125. Gladstone JP, Dodick DW, Evans R (2005) The young woman with postpartum "thunderclap" headache. Headache 45:70-74

126. Jaiser SR, Raman A, Maddison P (2008) Cerebral venous sinus thrombosis as a rare cause of thunderclap headache and nonaneurysmal subarachnoid haemorrhage. J Neurol 255:448-449

127. Cortez O, Schaeffer CJ, Hatem SF, Glauser J, Ahmed M (2009) Cases from the Cleveland Clinic: cerebral venous sinus thrombosis presenting to the emergency department with worst headache of life. Emerg Radiol 16:79-82

128. de Bruijn SF, Stam J, Kappelle $\sqcup$ (1996) Thunderclap headache as first symptom of cerebral venous sinus thrombosis. CVST Study Group Lancet 348(9042):1623-1625

129. McDonnell M, El-Bialy A (2008) The ache of a beating heart. Am J Med 121:956-959

130. Dodick DW, Eross EJ (2002) A not so uncommon cause of thunderclap headache. Headache 42:555

131. Weidauer S, Marquardt G, Seifert V, Zanella FE (2005) Hydrocephalus due to superior sagittal sinus thrombosis. Acta Neurochir 147:427-430. discussion 30

132. Chen S-P, Fuh J-L, Chang F-C, Lirng J-F, Shia B-C, Wang S-J (2008) Transcranial color doppler study for reversible cerebral vasoconstriction syndromes. Ann Neurol 63:751-757

133. Ducros A, Boukobza M, Porcher R, Sarov M, Valade D, Bousser MG (2007) The clinical and radiological spectrum of reversible cerebral vasoconstriction syndrome. A prospective series of 67 patients. Brain 130(Pt 12):3091-3101

134. Chen SP, Fuh JL, Lirng JF, Chang FC, Wang SJ (2006) Recurrent primary thunderclap headache and benign CNS angiopathy: spectra of the same disorder? Neurology 67(12):2164-2169

135. Koopman K, Teune LK, ter Laan M, Uyttenboogaart M, Vroomen PC, Keyser J, Luijckx GJ (2008) An often unrecognized cause of thunderclap headache: reversible cerebral vasoconstriction syndrome. J Headache Pain 9:389-391

136. Sharma P, Poppe AY, Eesa M, Steffenhagen N, Goyal M (2008) Postpartum thunderclap headache. Cmaj 179:1033-1035

137. Koopman K, Uyttenboogaart M, Luijckx GJ, De Keyser J, Vroomen PCA. (2007) Pitfalls in the diagnosis of reversible cerebral vasoconstriction syndrome and primary angiitis of the central nervous system. Eur I Neurol 14:1085-1087
138. Nowak DA, Rodiek SO, Henneken S, Zinner J, Schreiner R, Fuchs HH, Topka H (2003) Reversible segmental cerebral vasoconstriction (Call-Fleming syndrome): are calcium channel inhibitors a potential treatment option? Cephalalgia 23(3):218-222

139. Kirton A, Diggle J, Hu W, Wirrell E (2006) A pediatric case of reversible segmental cerebral vasoconstriction. Can J Neurol Sci 33:250-253

140. Nickele C, Muro K, Getch CC, Walker MT, Bernstein RA (2007) Severe reversible cerebral vasoconstriction syndrome mimicking aneurysmal rupture and vasospasm. Neurocrit Care 7:81-85

141. Keyrouz S, Dhar R, Axelrod Y (2008) Call-Fleming syndrome and orgasmic cephalgia. Headache 48:967-971

142. Elstner M, Linn J, Muller-Schunk S, Straube A (2009) Reversible cerebral vasoconstriction syndrome: a complicated clinical course treated with intra-arterial application of nimodipine. Cephalalgia 29:677-682

143. Saini M, Jeerakathil T, Butcher K (2009) Reversible cerebral vasoconstriction syndrome. Neurol India 57:63-65

144. Bouchard M, Verreault S, Gariepy J-L, Dupre N (2009) Intra-arterial milrinone for reversible cerebral vasoconstriction syndrome. Headache 49:142-145

145. Wong SH, Dougan C, Chatterjee K, Fletcher NA, White RP (2009) Recurrent thunderclap headaches and multilobar intracerebral haemorrhages: two cases of reversible cerebral vasoconstriction syndrome (RCVS). Cephalalgia 29:791-795

146. Oz O, Demirkaya S, Bek S, Eroglu E, Ulas U, Odabasi Z (2009) Reversible cerebral vasoconstriction syndrome: case report. J Headache Pain 10:295-298

147. Call GK, Fleming MC, Sealfon S, Levine H, Kistler JP, Fisher CM (1988) Reversible cerebral segmental vasoconstriction. Stroke 19:1159-1170

148. Whyte CA, Calabrese LH (2009) Reversible cerebral vasoconstriction syndrome. Headache 49:597-598

149. Zuber M, Touze E, Domigo V, Trystram D, Lamy C, Mas J-L (2006) Reversible cerebral angiopathy: efficacy of nimodipine. J Neurol 253:1585-1588

150. Edlow BL, Kasner SE, Hurst RW, Weigele JB, Levine JM (2007) Reversible cerebral vasoconstriction syndrome associated with subarachnoid hemorrhage. Neurocrit Care 7:203-210

151. Singhal $A B$ (2004) Postpartum angiopathy with reversible posterior leukoencephalopathy. Arch Neurol 61:411-416

152. Slivka A, Philbrook B (1995) Clinical and angiographic features of thunderclap headache. Headache 35:1-6

153. Singhal AB, Caviness VS, Begleiter AF, Mark EJ, Rordorf G, Koroshetz WJ (2002) Cerebral vasoconstriction and stroke after use of serotonergic drugs. Neurology 58:130-133

154. Dodick D, Brown R, Jr, Britton J, Huston J, III (1999) Nonaneurysmal thunderclap headache with diffuse, multifocal, segmental, and reversible vasospasm. Cephalalgia 19:118-123

155. Levy RL (1981) Stroke and orgasmic cephalgia. Headache 21:12-13

156. Jackson M, Lennox G, Jaspan T, Jefferson D (1993) Migraine angiitis precipitated by sex headache and leading to watershed infarction. Cephalalgia 13:427-430

157. Meschia JF, Malkoff MD, Biller J (1998) Reversible segmental cerebral arterial vasospasm and cerebral infarction: possible association with excessive use of sumatriptan and Midrin. Arch Neurol 55:712-714

158. Sturm JW, Macdonell RA (2000) Recurrent thunderclap headache associated with reversible intracerebral vasospasm causing stroke. [see comment]. Cephalalgia 20:132-135

159. Heckmann JG, Tomandl B, Kraus B, Gerlach R, Neundorfer B (2000) A case of diffuse cerebral vasospasm - Possibly ergotamine-associated? Cerebrovasc Dis 10:417-418

160. Dodick DW, Eross EJ, Drazkowski JF, Ingall TJ (2003) Thunderclap headache associated with reversible vasospasm and posterior leukoencephalopathy syndrome. Cephalalgia 23(10):994-997

161. Bartynski WS, Sanghvi A (2003) Neuroimaging of delayed eclampsia: report of 3 cases and review of the literature. J Comput Assist Tomogr 27:699-713

162. Foxford RJ, Sahlas DJ, Wingfield KA (2003) Vasospasm-induced stroke in a varsity athlete secondary to ephedrine ingestion. Clin J Sport Med 13:183-185

163. Lupo I, Saia V, Cammarata E, Giglia G, Palermo A, Mangiapane P (2004) Thunderclap headache and reversible posterior leukoencephalopathy: case report. Acta Medica Mediterranea 20:123-126

164. Schlegel D, Cucchiara B (2004) Orgasmic headache with transient basilar artery vasospasm. Headache $44: 710-712$

165. Valenca MM, Valenca LPAA, Bordini CA, da Silva WF, Leite JP, Antunes-Rodrigues J, Speciali JG (2004) Cerebral vasospasm and headache during sexual intercourse and masturbatory orgasms. Headache 44:244-248 
166. Renard D (2006) Cerebral vasospasm in idiopathic thunderclap headache. Neurology 67:990

167. Neudecker S, Stock K, Krasnianski M (2006) Call-Fleming postpartum angiopathy in the puerperium: a reversible cerebral vasoconstriction syndrome. [see comment]. Obstet Gynecol 107:446-449

168. Chen S-P, Fuh J-L, Lirng J-F, Wang S-J (2006) Is vasospasm requisite for posterior leukoencephalopathy in patients with primary thunderclap headaches? Cephalalgia 26:530-536

169. Kocak A, Sarac K, Ates O, Cayly SR (2007) Severe cerebral vasospasm caused by non-aneurysmal subarachnoid hemorrhage treatment with transluminal balloon angioplasty. Minim Invasive Neurosurg 50:23-26

170. Shalchian S, de Wispelaere F (2007) Call-Fleming syndrome: another case report. Headache 47:909-910

171. Schievink WI, Maya MM, Chow W, Louy C (2007) Reversible cerebral vasoconstriction in spontaneous intracranial hypotension. Headache 47:284-287

172. Honma K, Takizawa S, Ohtomo T, Takagi S (2007) MR findings in Call-Fleming syndrome. Intern Med 46:539-540

173. Moskowitz SI, Calabrese LH, Weil RJ (2007) Benign angiopathy of the central nervous system presenting with intracerebral hemorrhage. Surg Neurol 67:522-527

174. Moustafa RR, Allen CMC, Baron J-C (2008) Call-Fleming syndrome associated with subarachnoid haemorrhage: three new cases. I Neurol Neurosurg Psychiatry 79:602-605

175. Ramnarayan R, Sriganesh J (2009) Postpartum cerebral angiopathy mimicking hypertensive putaminal hematoma: a case report. Hypertens Pregnancy 28:34-41

176. Day JW, Raskin NH (1986) Thunderclap headache: symptom of unruptured cerebral aneurysm. Lancet 2:1247-1248

177. Dhuna A, Pascual-Leone A, Belgrade M (1991) Cocaine-related vascular headaches. J Neurol Neurosurg Psychiatry 54:803-806

178. Gold KJ, Barnes C, Lalley J, Schwenk TL (2005) Case report: late-onset eclampsia presents as bilateral cortical blindness. Am Fam Physician 71:856

179. Hoffmann J, Harms L, Klingebiel R (2009) Neurological picture. Reversible cerebral vasoconstriction associated with orgasmic headache. J Neurol Neurosurg Psychiatry 80:959

180. Kiemeneij IM, de Leeuw FE, Ramos LMP, van Gijn J (2003) Acute headache as a presenting symptom of tacrolimus encephalopathy. J Neurol Neurosurg Psychiatry 74:1126-1127

181. Kubo S, Nakata H, Tatsumi T, Yoshimine T (2002) Headache associated with postpartum cerebral angiopathy: monitoring with transcranial color-coded sonography. Headache 42:297-300

182. Looi JL, Christiansen JP (2006) Reversible posterior leukoencephalopathy associated with minimal change nephrotic syndrome. N Z Med J 119:U2257

183. Modi M, Modi G (2000) Case reports: postpartum cerebral angiopathy in a patient with chronic migraine with aura. Headache 40:677-681

184. Moussouttas M, Abubakr A, Grewal RP, Papamitsakis N (2006) Eclamptic subarachnoid haemorrhage without hypertension. J Clin Neurosci 13:474-476

185. Parameswaran BK, Krishnan PR, Al DJ (2007) Recurrent posterior reversible encephalopathy syndrome in a patient with sickle cell disease. Ann Saudi Med 27:206-211

186. Rosenbloom MH, Singhal AB (2007) CT angiography and diffusion-perfusion MR imaging in a patient with ipsilateral reversible cerebral vasoconstriction after carotid endarterectomy. AJNR Am J Neuroradiol 28:920-922

187. Silbert PL, Hankey GJ, Prentice DA, Apsimon HT (1989) Angiographically demonstrated arterial spasm in a case of benign sexual headache and benign exertional headache. Aust N Z J Med 19:466-468

188. Loewen AHS, Hudon ME, Hill MD (2004) Thunderclap headache and reversible segmental cerebral vasoconstriction associated with use of oxymetazoline nasal spray. Can Med Assoc J 171:593-594

189. Schievink WI, Wijdicks EFM, Meyer FB, Sonntag VKH, Barrow DL, Mayberg MR, Fleetwood IG, Steinberg GK, Weir BKA (2001) Spontaneous intracraniai hypotension mimicking aneurysmal subarachnoid hemorrhage. Neurosurgery 48:513-517

190. Kuo M-Y, Lien W-C, Wang H-P, Chen W-J (2005) Nontraumatic tension pneumocephalus-a differential diagnosis of headache at the ED. Am J Emerg Med 23:235-236

191. Evans RW (2007) Thunderclap headache associated with a nonhemorrhagic anaplastic oligodendroglioma. MedGenMed 9:26

192. Young WB, Silberstein SD (1997) Paroxysmal headache caused by colloid cyst of the third ventricle: case report and review of the literature. Headache 37:15-20
193. Jacome DE (2001) Transitional interpersonality thunderclap headache. Headache 41:317-320

194. Bhattacharyya N, Friedlander RM (2007) Pneumocephalus associated with pneumosinus dilatans frontalis. N Engl J Med 357:1136

195. Becker WJ (2002) Pneumocephalus as a cause for headache. Can J Neurol Sci 29:278-281

196. Hawley JS, Ney JP, Swanberg MM (2005) Subarachnoid pneumocephalus from epidural steroid injection. Headache 45:247-248

197. Krisanda TJ, Laucks SO (1994) Pneumocephalus following an epidural blood patch procedure: an unusual cause of severe headache. Ann Emerg Med 23:129-131

198. Laviola S, Kirvela M, Spoto MR, Tschuor S, Alon E (1999) Pneumocephalus with intense headache and unilateral pupillary dilatation after accidental dural puncture during epidural anesthesia for cesarean section. Anesth Analg 88:582-583

199. Smarkusky L, DeCarvalho H, Bermudez A, Gonzalez-Quintero VH (2006) Acute onset headache complicating labor epidural caused by intrapartum pneumocephalus. Obstet Gynecol 108:795-798

200. Asakura H, Hayashi Z, Seto M, Araki T (2001) Spontaneous intracranial hypotension during pregnancy. Obstet Gynecol 97:804-805

201. Broadley SA, Park N, Renowden S, Ferguson IT (2005) Unusual cause of sudden onset headache: spontaneous intracranial hypotension. Emerg Med Australas 17:520-523

202. Vaidhyanath R, Kenningham R, Khan A, Messios N (2007) Spontaneous intracranial hypotension: a cause of severe acute headache. Emerg Med J 24:739-741

203. Balgera R, Rigamonti A, Sozzi G, Agostoni E (2009) An atypical case of spontaneous intracranial hypotension. Neurol Sci 30:71-73

204. Ferrante E, Savino A (2005) Thunderclap headache caused by spontaneous intracranial hypotension. Neurol Sci 26:S155-S157

205. Famularo G, Minisola G, Gigli R (2005) Thunderclap headache and spontaneous intracranial hypotension. [comment]. Headache 45:392-393. author reply 3

206. Wang S-J, Fuh J-L (2005) Exertional but not postural headache resulting from spontaneous intracranial hypotension. Acta Neurol Taiwan 14:36-37

207. Buttner A, Winkler PA, Eisenmenger W, Weis S (1997) Colloid cysts of the third ventricle with fatal outcome: a report of two cases and review of the literature. Int J Legal Med 110:260-266

208. Mucchiut M, Valentinis L, Tuniz F, Zanotti B, Skrapp M, Bergonzi P, Zanchin G (2007) Adult aqueductal stenosis presenting as a thunderclap headache: a case report. Cephalalgia 27:1171-1173

209. Lasoasa DS (2003) Not-so-benign sexual headache. Headache 43:808

210. Reeder JD, Wolf J, Andelman S, Andrew BJ (1990) The cough/laugh syndrome: MR evaluation. AJNR Am J Neuroradiol 11:1022

211. Titlic M, Jukic I, Kolic K, Rogosic V, Josipovic-Jelic Z (2008) An acute headache and hydrocephalus caused by the dermoid cyst. Bratisl Lek Listy 109:580-581

212. Galer BS, Lipton RB, Weinstein S, Bello L, Solomon S (1990) Apoplectic headache and oculomotor nerve palsy: an unusual presentation of multiple sclerosis. [see comment]. Neurology 40:1465-1466

213. Nishioka H, Ito H, Miki T, Hashimoto T, Nojima H, Matsumura H (1999) Rathke's cleft cyst with pituitary apoplexy: case report. Neuroradiology 41:832-834

214. Nishioka H, Haraoka J, Izawa H, Ikeda Y (2006) Headaches associated with Rathke's cleft cyst. Headache 46:1580-1586

215. Altay H, Kitis O, Calli C, Yunten N (2006) A spinal dermoid tumor that ruptured into the subarachnoidal space and syrinx cavity. Diagn Interv Radiol 12:171-173

216. Cayli SR (2000) Arachnoid cyst with spontaneous rupture into the subdural space. Br J Neurosurg 14:568-570

217. Rozen TD (2002) Thunderclap headache with diplopia and anorexia. Neurology 59:461

218. Cryer RJ, Ferriman D (1971) Pituitary apoplexy. Proc R Soc Med 64:301-302

219. Garza I, Kirsch J (2007) Pituitary apoplexy and thunderclap headache. Headache 47:431-432

220. Epstein S, Pimstone BL, De Villiers JC, Jackson WP (1971) Pituitary apoplexy in five patients with pituitary tumours. Br Med J 2:267-270

221. Espinosa PS, Choudry B, Wilbourn R, Espinosa PH, Vaishnav AG (2007) Pituitary apoplexy: a neurological emergency case report. J Ky Med Assoc 105:538-540 
222. Kuzma BB, Goodman JM (1999) Sudden headache with pituitary infarction. Surg Neurol 52:532-533

223. Markowitz S, Sherman L, Kolodny HD, Baruh S (1981) Acute pituitary vascular accident (pituitary apoplexy). Med Clin N Am 65:105-116

224. Sani S, Smith A, Leppla DC, llangovan S, Glick R (2005) Epidermoid cyst of the sphenoid sinus with extension into the sella turcica presenting as pituitary apoplexy: case report. Surg Neurol 63:394-397

225. Randeva HS, Schoebel J, Byrne J, Esiri M, Adams CB, Wass JA (1999) Classical pituitary apoplexy: clinical features, management and outcome. Clin Endocrinol (Oxf) 51:181-188

226. Hoff JI, Bloem BR, Ferrari MD, Lammers GJ (2004) A breathtaking headache. [comment]. J Neurol Neurosurg Psychiatry 75:509

227. Amendo MT, Brown BA, Kossow LB, Weinberg FM (2001) Headache as the sole presentation of acute myocardial infarction in two elderly patients. Am J Geriatr Cardiol 10:100-101

228. Broner S, Lay C, Newman L, Swerdlow M (2007) Thunderclap headache as the presenting symptom of myocardial infarction. Headache 47:724-725

229. Seow V-K, Chong C-F, Wang T-L, Ong J-R (2007) Severe explosive headache: a sole presentation of acute myocardial infarction in a young man. Am J Emerg Med 25:250-251

230. Dalzell JR, Jackson CE, Robertson KE, McEntegart MB, Hogg KJ (2009) A case of the heart ruling the head: acute myocardial infarction presenting with thunderclap headache. Resuscitation 80:608-609

231. Lefkowitz D, Biller J (1982) Bregmatic headache as a manifestation of myocardial ischemia. Arch Neurol 39:130

232. Korantzopoulos P, Karanikis P, Pappa E, Dimitroula V, Kountouris E, Siogas K (2005) Acute non-ST-elevation myocardial infarction presented as occipita headache with impaired level of consciousness-a case report. Angiology 56:627-630

233. Nohe B, Ernemann U, Tepe G, Ritz R, Bail D (2005) Aortic dissection mimicking subarachnoidal hemorrhage. Anesth Analg 101:233-234

234. Singh S, Huang JY, Sin K, Charles RA (2007) Headache: an unusual presentation of aortic dissection. Eur J Emerg Med 14:47-49

235. Stollberger C, Finsterer J, Fousek C, Waldenberger FR, Haumer H, Lorenz W (1998) Headache as the initial manifestation of acute aortic dissection type A. Cephalalgia 18:583-584

236. Heo YE, Kwon HM, Nam HW (2009) Thunderclap headache as an initial manifestation of phaeochromocytoma. Cephalalgia 29:388-390

237. Khan O, Williams G (1981) Micturition with headache: phaeochromocytoma of the bladder. Eur Urol 7:112-114

238. Adinma J (1994) Acute puerperal coital headache and hypertension. [see comment]. Aust N Z J Obstet Gynaecol 34:487-488

239. Nishimoto H, Ogasawara K, Miura K, Ohmama S, Kashimura H, Ogawa A (2005) Acute intracranial hypertension due to occlusion of the brachiocephalic vein in a patient undergoing hemodialysis. Cerebrovasc Dis 20:207-208

240. Biran I, Steiner I (2002) Coital headaches induced by amiodarone. Neurology 58:501-502

241. Straube A, Plendl H, Bruening R (2006) Idiopathic thunderclap headache: reversible vasospasm of the Arteria basilaris. Nervenarzt 77:1232-1234

242. Shimada J, Takeda N, Yamauchi S, Urushibara T, Kawaguchi H (2004) Reversible posterior leukoencephalopathy syndrome: experience in 3 cases. No To Shinkei 56(12):1036-1041

243. Schmidt D (1982) Coital headache. Schweiz Med Wochenschr 112(30):1068-1069

244. Santos S, Larrode-Pellicer P, Iniguez-Martinez C, Perez-Lazaro C, Claramonte M, Alberti-Gonzalez O, Martinez L (2006) Sexual headaches associated to an arachnoid cyst. Rev Neurol 42:381-382

245. Rubiera-Del Fueyo M, Molina-Cateriano CA, Arenillas-Lara JF, Pelayo-Vergara R, Santamarina E, Romero-Vidal FJ, Alvarez-Sabin J (2004) Reversible segmental cerebral vasoconstriction: the value of duplex transcranial doppler in its diagnosis and follow-up. Rev Neurol 38:530-533

246. Romero-Blanco M, Monteiro E, Joao G (2001) Sexual headache associated with intracranial tumour. Rev Neurol 33:100

247. Nicolle M, Hugues F (1981) A propos d'une cause rare de cephalee paroxystique, le kyste colloide du troisieme ventricule. Semaine des Hopitaux Paris 57:386-388

248. Ni J, Cui L-y (2009) Reversible cerebral vasoconstriction syndrome: one case report and review of the literature. Chinese Journal of Contemporary Neurology and Neurosurgery 9:31-34

249. Laubach S, Reber A (2004) Subarachnoid haemorrhage after spinal anaesthesia for caesarean section. Anaesthesist 53:723-726
250. Koga Y, Isobe N, Tateishi T, Osoegawa M, Ohyagi Y, Kira J (2008) Case of posterior reversible encephalopathy syndrome with cerebral vasoconstriction. Rinsho Shinkeigaku 48(5):355-358

251. Ichiki M, Watanabe O, Okamoto Y, Ikeda K, Takashima H, Arimura K (2008) A case of reversible cerebral vasoconstriction syndrome (RCVS) triggered by a Chinese herbal medicine. Rinsho Shinkeigaku 48(4):267-270

252. Hurtarte-Sandoval AR, Saenz-Alegria RA, Hernandez-Mejia J (2009) Reversible posterior leukoencephalopathy syndrome caused by pre-eclampsia. Rev Neurol 48:110-111

253. Hashimoto $Y$, Kaneko T, Morita E, Ohtaki M (2002) Serial magnetic resonance angiography in a case with isolated angiitis of the CNS. No Shinkei Geka 30:993-998

254. Hamasaki O, Sakamoto S, Nakahara T, Sakota K (2001) A case with diffuse vasospasm after perimesencephalic nonaneurysmal subarachnoid hemorrhage. No To Shinkei 53:1051-1055

255. Gossrau G, Dannenberg C, Reichmann H, Sabatowski R (2008) Thunderclap headache caused by cerebellar infarction. Schmerz 22(1):82-86

256. Gomez M, Aguirre J, Valverde-Grimaldi C, Berenguer A (1995) Sexual headache and cerebral hemorrhage. Rev Neurol 23:184-185

257. Gomez PA, Campollo J, Lobato RD, Lagares A, Alen JF (2001) Subarachnoid hemorrhage secondary to dissecting aneurysms of the vertebral artery. Description of 2 cases and review of the literature. Neurocirugia (Astur) 12(6):499-508

258. Garcia-Estevez DA, Lopez-Real A (2008) Ischaemic stroke and sexual headache. Rev Neurol 47:108-109

259. Fuentes S, Metellus P, Adetchessi T, Dufour H, Grisoli F (2006) Idiopathic acute obstructive hydrocephalus. Case report. Neurochirurgie 52:47-51

260. Domitrz I (2005) Primary headache associated with sexual activity. Ginekol Pol 76:995-999

261. Bogucki A, Niewodniczy A (1984) A case of headache occurring during sexual intercourse. Pol Tyg Lek 39(13):451-452

262. Bo SH, Rud EK, Kravdal GS (2005) Subarachnoidal haemorrhage with spectrophotometric detection of bilirubin in the spinal fluid as the only pathological result. Tidsskrift for Den Norske Laegeforening 125:2192-2194

263. Abenza Abildua MJ, Fuentes Martinez Sanchez B, Martinez Sanchez P (2009) Sudden headache after lumbar puncture: pneumoencephalus. Neurologia 24:79-80

264. Takeuchi T, Kasahara E, Iwasaki M, Higuchi M, Kojima S (1994) Necessity of cerebral angiography in thunderclap headache patients who show no evidence of subarachnoid hemorrhage: investigation of 350 cases. No Shinkei Geka 22:925-931

265. Takeuchi T, Kasahara E, Iwasaki M, Kojima S (1996) Necessity for searching for cerebral aneurysm in thunderclap headache patients who show no evidence of subarachnoid hemorrhage: investigation of 8 minor leak cases on operation. No Shinkei Geka 24:437-441

266. Salloum A, Lebel M, Reiher J (1977) Headache simulating meningeal hemorrhage. Rev Neurol 133:131-138

267. Rousseaux P, Scherpereel B, Bernard MH, Guyot JF (1983) Acute benign cerebral angiopathy. 6 cases. Presse Med 12:2163-2168

268. Nick J, Bakouche P (1980) Headache related to sexual intercourse (author's transl). Semaine des Hopitaux 56:621-628

269. Michel D, Vial C, Antoine JC, Laurent B, Portafaix M, Trillet M (1985) Benign acute cerebral angiopathy. 4 cases. Rev Neurol 141:786-792

270. Ito Z, Suzuki A, Nakajima K, Kutsusawa T (1976) Warning symptoms of rupture in cerebral aneurysm. Nippon Rinsho 34:123-130

271. Dimitrijevic J, Dzirlo K, Loncarevic N, Gordana B (2005) Acute strong headache in emergency neurology (diagnostic and treatment). Med Arh 59:102-105

272. Strittmatter M, Zimmermann C, Schimrigk K, Hamann GF (1996) Thunder clap headache: an independent form of headache? Wien Klin Wochenschr 108:326-329

273. Staszewski J, Kotowicz J (2004) Acute, stroke or thunderclap headache? Pol Merkur Lekarski 16:539-542

274. Ekusheva EV, Filatova EG (2003) Headache caused by sexual activity. Zh Nevrol Psikhiatr Im S S Korsakova 103:21-25

275. Ducros A, Bousser MG (2013) Thunderclap headache. BMJ 346:e8557

276. Sattar A, Manousakis G, Jensen MB (2010) Systematic review of reversible cerebral vasoconstriction syndrome. Expert Rev Cardiovasc Ther 8(10):1417-1421

277. Sjaastad O, Bakketeig LS (2008) Prevalence of cervicogenic headache: vaga study of headache epidemiology. Acta Neurol Scand 117(3):173-180 
278. Yeh YC, Fuh JL, Chen SP, Wang SJ (2010) Clinical features, imaging findings and outcomes of headache associated with sexual activity. Cephalalgia 30(11):1329-1335

279. Mathys J, Lachat M, Herren T (2004) Headache as a manifestation of a life-threatening vascular disorder. Headache 44:706-709

280. Ramaraj R (2008) Sudden onset of headache and recent breathlessness. BMJ 337:a1844

281. Takayanagi K, Fujito T, Morooka S, Takabatake Y, Nakamura Y (1990) Headache angina with fatal outcome. Jpn Heart J 31:503-507

282. Ishida A, Sunagawa O, Touma T, Shinzato Y, Kawazoe N, Fukiyama K (1996) Headache as a manifestation of myocardial infarction. Jpn Heart $J$ $37: 261-263$

283. Greiner F, Rothrock J (2006) Thunderclap headache, cardiopulmonary arrest, and myocardial infarction. Headache 46:512

284. Calabrese LH, Dodick DW, Schwedt TJ, Singhal AB (2007) Narrative review: reversible cerebral vasoconstriction syndromes. Ann Intern Med 146:34-44

285. Sathirapanya P, Setthawatcharawanich S, Limapichat K, Phabphal K (2013) Thunderclap headache as a presentation of spontaneous spinal epidural hematoma with spontaneous recovery. J Spinal Cord Med 36(6):707-710

286. Verillaud B, Ducros A, Massiou H, Huy PT, Bousser MG, Herman P (2010) Reversible cerebral vasoconstriction syndrome in two patients with a carotid glomus tumour. Cephalalgia 30(10):1271-1275

287. Uchida Y, Matsukawa N, Oguri T, Sakurai K, Miura T, Iwagaitsu, Naniwa ST, Ojika K (2011) Reversible cerebral vasoconstriction syndrome in a patient with Takayasu's arteritis. Intern Med 50(15):1611-1614

288. Ducros A (2005) Thunderclap headache. Rev Neurol 161:713-715

doi:10.1186/1129-2377-15-49

Cite this article as: Devenney et al:: A systematic review of causes of sudden and severe headache (Thunderclap Headache): should lists be evidence based? The Journal of Headache and Pain 2014 15:49.

\section{Submit your manuscript to a SpringerOpen ${ }^{\circ}$ journal and benefit from:}

- Convenient online submission

- Rigorous peer review

- Immediate publication on acceptance

- Open access: articles freely available online

- High visibility within the field

- Retaining the copyright to your article

Submit your next manuscript at $\gg$ springeropen.com 